\title{
ASSESS THE PATIENT SATISFACTION ON THE MEDICAL, NURSING \& SUPPORTIVE HEALTH CARE SERVICES OF THE HOSPITAL AND DOCTORS' \& NURSES' PERCEPTION ABOUT THEIR HEALTH CARE SERVICES IN SELECTED HOSPITAL OF U.T OF DADRA \& NAGAR HAVELI
}

\section{Ms. Fiby N Samuval*}

Postgraduate, Shri Vinoba Bhave College of Nursing, Silvassa, DNH. ${ }^{*}$ Corresponding Author

Professor cum Vice Principal, Shri Vinoba Bhave College of Nursing, Silvassa, DNH.

\section{Mr. Jerin Rajan} Assistant Professor, Shri Vinoba Bhave College of Nursing, Silvassa, DNH.

ABSTRACT Background: Patients are the backbone of the health care system, their judgment and feedback of quality of hospital services is essential in monitoring \& improving the quality of care. Nurses and doctors are the important members of health care team. So, firstly, they themselves to be satisfied then only the patients will be satisfied with their services.

Aim: The study was to assess the patient satisfaction on health care services and to identify nurses \& doctors perception about their health care services.

Methods: A qualitative survey approach with correlational crossectional survey design was used to collect data from the 200 inpatients, 60 nurses and 20 doctors of surgical, medical, orthopedics, gynecological \& obstetrical wards at Shri Vinoba Bhave Civil Hospital, Silvassa. Patients were selected by propotionate Stratified randomly sampling technique and doctors and nurses by convenient sampling technique.

Results: The finding shows that $73 \%$ patients are highly satisfied with the admission procedures. $92 \%$ patients are highly satisfied with the doctor's services. $75 \%$ patients are highly satisfied with the nursing services and diagnostic test facilities. 87 $\%$ patients are highly satisfied with the physical facilities available in the ward. $100 \%$ doctors \& $98.3 \%$ nurses perceived that they are giving good quality of services to the patient. There was a positive correlation between the patient satisfaction and perception scores of nurses $(r=0.38) \&$ doctors $(r=0.66)$ on their services provided to the patient. There was a significant association between patient satisfaction and Place and area of residence, gender, educational status, duration of hospitalization and status of health at the time of discharge of the patients at 0.05 level of significance.

Conclusion: The present study result shows patients are satisfied with the health care services provided in Shri Vinoba Bhave Civil Hospital, Silvassa. Moreover, there was a positive relationship between patient satisfaction and nurses' and doctors perception.

\section{KEYWORDS : Patient Satisfaction, Perception, Perceptual Incongruence, Monitoring}

\section{INTRODUCTION}

A hospital is a health-care institution providing patient treatment with specialized medical staff, nursing staff and other professional staff \& also delivers services 24 hours per day, 7 days per week. They offer a varying range of acute, long-term \& terminal care using diagnostic \& curative services. As the health care scenario is changing rapidly, the hospital need to improve the quality in healthcare delivery system to remain competitive. And the quality of care provided by an institution is individualized \& patient oriented.

Health care team is the health personnel's of the health-care institution which plays a major role in delivering satisfactory care to the patients and brings profit to the institution. Nurses and doctors are the important members of health care team. The nature of giving care is not only the matter, but the behavior and attitude of the health personnel also affects the patient satisfaction. Firstly, they themselves to be satisfied with the care or the services provided by them then only the person (patients) who receives the care will be satisfied with their services.

Patient satisfaction is of greater importance for the health care institution as it helps to understand the need and expectation of patient. The lifestyle of the people is modifying, so their needs and expectation are also changing day by day. Therefore, it is necessary to innovate the healthcare services to remain competitive in health care market. That's why it is necessary to do periodic monitoring and evaluation of the services and to take feedback from the patient about the health care services provided in the hospital.

\section{Objectives Of The Study}

1. To assess the patient satisfaction on the health care services provided in the hospital.

2.To assess the nurses' perception on nursing care services provided to the patients.

3.To assess the doctors' perception on medical care services provided to the patients.

4.To correlate the patient's satisfaction \& doctor's perception about Medical care services provided to the patients.

5. To correlate the patient's satisfaction \& nurses' perception about Nursing care services provided to the patients.

6. To find the association between level of patients satisfaction \& their selected demographic variables.

\section{METHODS AND MATERIALS}

Research Approach:

The qualitative survey approach was found to be consistent with the purpose of the study.

\section{Research Design:}

A correlational crosssectional survey design was used for this present study to assess the patient satisfaction on the healthcare services and nurses' \& doctors' perception about their healthcare services provided to the patient.

\section{Setting Of The Study:}

The study was conducted in Shri Vinoba Bhave Civil Hospital, Silvassa.

Population:

In the present study population comprised of the patients, 
doctors and nurses of Shri Vinoba Bhave Civil Hospital, Silvassa. The samples were selected from surgical, medical, orthopedics, Gynecological \& Obstetrical wards of Shri Vinoba Bhave Civil Hospital, Silvasa.

Sample And Sampling Technique:

200 in-patients of surgical, medical, orthopedics, Gynecological \& Obstetrics wards hospitalized for atleast 3 days were selected using Proportionate stratified random sampling techniques, 60 Nurses(Nursing officer and Senior Nursing Officer) and 20 doctors (Medical officers \& Residents) of the surgical, medical, orthopedics, Gynecological \& Obstetrics wards were selected as samples for the study by using Convenient Sampling Technique.

\section{Data Collection:}

The data were collected by administering the tool to 200 patients, 60 nurses and 20 doctors of Shri Vinoba Bhave Civil Hospital, Silvassa. Tools were given to the willing nurses and doctors (medical officer, Residents) of surgical, medical, orthopedics, gynecological \& obstetrical wards and to the patients of surgical, medical, orthopedics, gynecological \& obstetrical wards. Randomly selected 50 patients from each ward, 25 male and 25 female were selected by matching the age and area of residence. But from Obstetrical \& Gynecological ward, only 50 females were selected.

Therefore, the following tools were used in order to obtain the data.

\section{For Patients:}

Section-A: Demographic Data

Section-B: Patient Satisfaction tool

\section{For Nurses:}

Section -A: Demographic Data

Section -B: Tool regarding Nurses Perception about health care services

\section{For Doctors:}

Section -A: Demographic Data

Section -B: Tool Regarding Doctors Perception about health care services

\section{Criteria For Selection Of Sample: \\ Inclusion Criteria: \\ Group 1: Patients}

a. Males and females of 18 or more than 18years of age who are willing to participate and available during the study.

b. Who are admitted in surgical, medical, orthopedics and Gynecological \& Obstetrical wards for at least 3 days.

c. Who can read, write and understand Hindi or Guajarati.

\section{Group 2: Nurses}

a) Nurses who are willing to participate.

b) Who had basic nursing training programme as diploma, post basic diploma, graduates.

c) Minimum six months of clinical experience.

\section{Group 3: Doctors}

a) Males and females, who are willing to participate in the study.

b) Minimum six months of clinical experience.

c) Graduates or post-graduates registered and licensed under medical Council of India as medical, surgical, orthopedic and Obstetrical practitioner and are full time employees of any cadre, in Shri Vinoba Bhave Civil Hospital.

\section{Exclusion Criteria:}

Group 1: Patients

a) Patients who are unconscious or semiconscious.

b) Patients who are physically challenged \& or not able to communicate or respond.

c) Patients who are mentally ill and do not give reliable answers.

d) Patient who are hospitalized for less than 3 days.

\section{Group 2: Nurses}

a) Nurses who are unwilling to participate.

b) Nurses who are not registered to the nursing council.

c) Nurses who are not having minimum six months of clinical.

\section{Group 3: Doctors}

a) Doctors, who are unwilling to participate in the study.

b) Doctors, who are not having minimum six months of clinical experience.

c) Doctors other than the medical officer, junior resident, senior resident.

\section{RESULTS:}

The data were grouped and analyzed by using descriptive and inferential statistical methods.

\section{The Result Showed That:-}

- The patients were highly satisfied with the billing facilities available in the hospital, in which the mean percentage is 92.15 , then with the dietary services in which the mean percentage is 91.06. After that, with the discharge procedures and doctors' services in which the mean percentages were $90.75 \& 90.6$. Low satisfaction is seen in diagnostic test facilities, admission procedures, nursing care and procedures in which mean percentages were $79.96,82.49$, and 82.76. Average satisfaction of the patient is seen in cleanliness of the unit, toilet, bathroom \& and also with physical infrastructure of the ward, in which mean percentages are $89.53,87.17 \& 84.46$ respectively.

Table 1

- 77 (38.5\%) patients availed the emergency services; among this the mean of satisfaction of patient with the Emergency Services is 27.93 with the standard deviation of 2.97. Table 2

- All the 20 (100\%) doctors perceived that they were giving good quality of medical services to the patient.

- $59(98.3 \%)$ nurses perceived that they were giving quality of nursing services to the patient and $1(1.66 \%)$ nurses are moderately satisfied with the nursing care which they provide to the patient in the hospital.

- There is a positive correlation $(r=0.38)$ between the patient satisfaction and perception scores of nurses on nursing care services provided to the patients. So, the research hypothesis is accepted and null hypothesis is rejected. Graph 1

- There is a positive correlation $(r=0.66)$ between the patient satisfaction and perception scores of doctors on medical care services provided to the patient. So, the research hypothesis is accepted and null hypothesis is rejected. Graph 2

- There is a significant association between patient satisfaction \& selected demographical variables i.e. Place of residence, Area of residence Gender, Educational 
status, Occupation, Duration of hospitalization, Prior hospitalization of patient and their family members in SVBCH, Status of the patient at the time of discharge at the $\mathrm{p}<0.05$ level of significance.

Table 1-Mean, Mean Percentage And Standard Deviation Of The Patient Satisfaction With The Healthcare Services $\mathrm{N}=200$

\begin{tabular}{|l|l|l|l|l|l|l|}
\hline S.no & Topic & $\begin{array}{l}\text { No. of } \\
\text { items }\end{array}$ & $\begin{array}{l}\text { Max. } \\
\text { Marks }\end{array}$ & Mean & $\begin{array}{l}\text { Mean } \\
\%\end{array}$ & S.D \\
\hline 1. & $\begin{array}{l}\text { Related to } \\
\text { admission } \\
\text { procedure }\end{array}$ & 10 & 50 & 41.245 & 82.49 & 7.30 \\
\hline 2. & $\begin{array}{l}\text { Related to Doctor's } \\
\text { services }\end{array}$ & 12 & 48 & 43.495 & 90.60 & 5.25 \\
\hline 3. & $\begin{array}{l}\text { Related to Nursing } \\
\text { Care / procedures }\end{array}$ & 17 & 68 & 56.28 & 82.76 & 9.22 \\
\hline 4. & $\begin{array}{l}\text { Services related to } \\
\text { diagnostic test } \\
\text { facilities }\end{array}$ & 6 & 24 & 26.39 & 79.96 & 3.42 \\
\hline 5. & $\begin{array}{l}\text { Related to } \\
\text { infrastructure/ } \\
\text { Physical facilities }\end{array}$ & 13 & 52 & 43.925 & 84.46 & 20.22 \\
\hline 6. & $\begin{array}{l}\text { Related to } \\
\text { Cleanliness of the } \\
\text { unit }\end{array}$ & 3 & 15 & 14.325 & 89.53 & 2 \\
\hline 7. & $\begin{array}{l}\text { Related to toilet/ } \\
\text { bathroom of the } \\
\text { ward }\end{array}$ & 5 & 20 & 17.435 & 87.175 & 2.38 \\
\hline 8. & $\begin{array}{l}\text { Related to Dietary } \\
\text { Services }\end{array}$ & 7 & 35 & 32.785 & 91.06 & 4.01 \\
\hline 9. & $\begin{array}{l}\text { Related to Billing } \\
\text { Facilities }\end{array}$ & 4 & 20 & 18.43 & 92.15 & 2.62 \\
\hline 10. & $\begin{array}{l}\text { Related to } \\
\text { Discharge } \\
\text { Procedures }\end{array}$ & 4 & 16 & 14.52 & 90.75 & 1.92 \\
\hline 11. & $\begin{array}{l}\text { Overall Rating of } \\
\text { the Health care } \\
\text { Services }\end{array}$ & 1 & 4 & 3.505 & 87.62 & 0.54 \\
\hline
\end{tabular}

Table 2: Mean, Mean Percentage And Standard Deviation Of The Patient Satisfaction With The Emergency Services $\mathrm{N}=77$

\begin{tabular}{|l|c|c|c|c|c|}
\hline Topic & $\begin{array}{l}\text { No. of } \\
\text { items }\end{array}$ & $\begin{array}{l}\text { Max. } \\
\text { Marks }\end{array}$ & Mean & $\begin{array}{c}\text { Mean } \\
\%\end{array}$ & S.D \\
\hline $\begin{array}{l}\text { Related to Emergency } \\
\text { Services }\end{array}$ & 07 & 28 & 27.93 & 96.31 & 2.97 \\
\hline
\end{tabular}

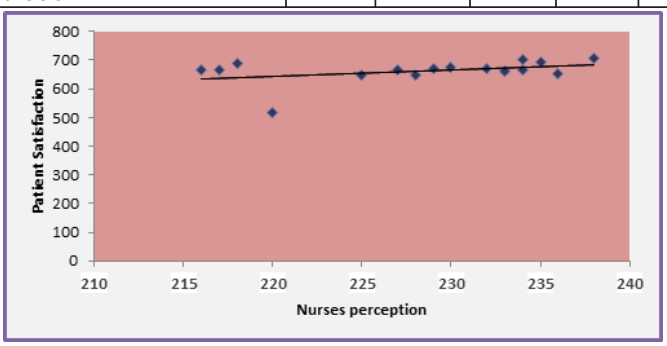

Graph 1: Scattered Diagram Showing A Correlation Between The Nurses' Perception And The Patient Satisfaction About The Nursing Services

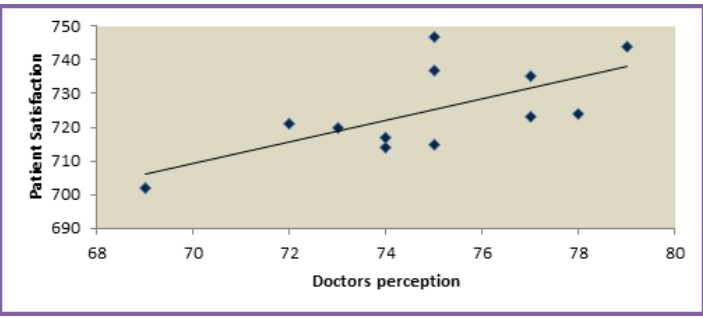

Graph 2: Scattered Diagram Showing A Correlation
Between The Doctors' Perception And The Patient Satisfaction About The Medical Services

\section{CONCLUSION}

The conclusion of the present study reveals that the patients were satisfied with the health care services provided in Shri Vinoba Bhave Civil Hospital, Silvassa and also reveals that there was a positive correlation between patient satisfaction and Nurses' and Doctors' perception about their health care services. Overall results of the study show a positive relationship between patient satisfaction and nurses' and doctors' perception. Positive and good behaviors of the health care provider are most important for any organization, especially in a healthcare organization. They play important roles in patient satisfaction. So, the patient satisfaction should be assessed periodically as the life styles of the people are changing meanwhile the expectations of the people will also change.

\section{REFERENCES}

1) Wagner D and Bear M. Patient Satisfaction with Nursing Care: A Concep Analysis within a Nursing Framework. Journal of Advanced Nursing 2009; 65 692-701.

2) Subedi durga, K Uprety. Patients' satisfaction with hospital services in Kathmandu journal of Chitwan medical college 2014; 4(9): 25-31.

3) T Rajeswari. A study to assess patient's satisfaction with quality of nursing care. 2011. Available at: dspace.sctimst.ac.in/jspui/bitstream/123456789/ 1607/1/481.pdf.

4) Elwin Shawa. Patients' Perceptions Regarding Nursing Care in the General Surgical Wards at Kenyatta National Hospital. 2012. Available at http://hdl.handle.net/10755/621210

5) Dr Darpan Toke, Dr Ashish Gupta, Dr Achal Gupta. An observational study to assess the level of satisfaction amongst patients operated as elective basis in department of surgery, G.R. Medical College \& JA group of hospitals. IOSR Journal of Dental and Medical Sciences (IOSR-JDMS) Jan 2017, 16(1):68-96. Available at: www.iosrjournals.org

6) Joshi KJ, Sochaliya K, Purani S, Kartha G. Patient satisfaction about health care services: A cross sectional study of patients who visit the outpatient department of a civil hospital at Surendranagar, Gujarat. Int J Med Sci Public Health 2013. 2.659-663

7) Kumari R, Idris M, Bhushan V, Khanna A, Agarwal M, Singh S. Study on patient satisfaction in the government allopathic health facilities of Lucknow district, India. Indian J Community Med. 2009; 34(1):35-42.

8) Ghose Seetesh, Vivek .S. Patient Satisfaction with medical Services: A Hospital-Based Study. Health and population-perspectives. 2011:34(4), 232-234.

9) Rose Marie Nieswiadomy. Foundations of Nursing Research. $3^{\text {rd }}$ ed. Appleton and Lange Prentice Hall international ltd; 1998.

10) Denise F Polit, Bernadette P Hungler. Nursing Research Principles and Methods. $6^{\text {th }}$ ed. Philadelphia, New York. Lippincott Publishers; 1999. 